\title{
Insects Thasus gigas Burm (Xamuis) to the problem of Diabetes in Actopan Hidalgo, Mexico.
}

\author{
${ }^{1}$ Calderón Nava Oscar Esaú, ${ }^{1}$ Pérez Hernández Itzel, ${ }^{1}$ Cruz Almaraz Luis \\ Daniel, *2Ruvalcaba Ledezma Jesús Carlos. \\ ${ }^{I}$ Students of the Bachelor of Medicine and Health (ICSA-UAEH) Institute of Health Sciences, University of \\ Hidalgo State. Pachuca City, Hidalgo State, Mexico. \\ $*^{2}$ Full-time Research Professor in medical academic (ICSA-UAEH) Institute of Health Sciences, University of \\ Hidalgo State. Pachuca City, Hidalgo State, Mexico
}

\begin{abstract}
Type 2 diabetes mellitus continues to increase around the world and this has cause the seeking of alternative therapies, amongst them the ingestion of insects such as Thasus gigas burn. Objective To analyze the use of the insect Thasus gigas Burm, (Xamuis), in the treatment aimed to control type 2 Diabetes Mellitus based on the opinion of the adults within the Actopan, Hidalgo population. Methodology. A transverse descriptive study of observational characteristic. Results. The knowledge about these insects seems to be prominent amongst the women, a group in which the disease also dominates; apparently they consume the insects based on empirical knowledge. Conclusion. It is necessary to conduct research in which the effect of the consumption on the levels of glucose of such insects is evaluated.
\end{abstract}

Key words: Thasus gigas Burm, Diabetes, empirical knowledge, glucose.

\section{INTRODUCTION}

Diabetes Mellitus Type 2 caused by two factors a) a dysfunction of the beta cells, with a deficiency on the secretory response to the serum glucose stimulus, and b) a peripheral resistance to insulin's biological effects, from the decrease in number of insulin receptors as well as the post membrane receptors, all of which leads to an excess in the production of glucose by the liver and difficulties in its capturing by the muscle and adipocytes. [1]

Some authors believe that the primary defect can be found within the beta cell, with the deterioration of the secretion of insulin. On the other hand the primary cause has been identified within the insulin-resistance based off the fact that obesity produces insulin-resistance and that the decrease in body weight reduces the possibility of developing Diabetes Mellitus. [1]

According to the Official Mexican Norm for the prevention, Treatment and Control of Diabetes, NOM-015-SSA2-1994, the treatment must consider the establishment of goals, a non pharmacological management which includes education, auto-monitoring, pharmacological management and surveillance for complications. [2]

The non-pharmacological management includes: weight control, a nutrition plan, education of the patient as well as their family, auto-monitoring, and finally support groups. The pharmacological management includes the medications that are used for the control of the diabetes, which includes sulfonylureas, Biguanides, insulin or a combination of these. Alpha-glycosidase inhibitors, thiazolidinediones, and other options can also be used. [1-4]

The Zapotec, Mixtec and Mayan cultures made use of the insects to relieve digestive, respiratory, nervous, circulatory and bone diseases such as the jumils, which were used as anesthetics and analgesic. The consumption of insects as part a diet or Entomophagy has been practice in endemic regions of our territory since pre-hispanic times, proof of that is described in the Cóndice Florentino written by Fray Bernardino of Sahagún and his informants during the colonization, where there are 96 species of insects described. The edible beetles are of the Coleoptera species. There are 88 species of the Coleoptera order in existence that are consumed in México, primarily their larvae (in the states of Hidalgo, Tabasco, Guerrero, Veracruz, Oaxaca, Puebla, Distrito Federal, Nayarit, Chiapas y Michoacán. [5,6] 
Chahuis o xamoes are the names given in Mexico to a variety of edible beetles that feed on the Prosopis spp tree. [6]

According to the data obtained the Xamoes must be captured by the head, in order to make them empty a yellow liquid with a less than desirable smell which they use as a defense mechanism. Its preparation is similar to that of the grasshoppers: they are deposited into a bucket of water and lime and are left to rest. Which discards the vendor's theory, for the sour taste which he mentioned comes from the substance that the beetle lets out.

These are much included in the typical Mexican food for their flavor, in fact there is a rumor amongst the farmers about which insects are ingested in the diets of the people with diabetes Mellitus, for its sweet taste and the comfort it brings up the palette, now that as we know these type of patients have restricted in their diet the sweeteners that can produce too much glucose, reason for which this alternative is welcomed amongst them.

They are also cooked in lemon and salt and grilled alive in the skillet pan and are cooked with sauce to be eaten immediately with corn tortillas or by themselves. They are used as meatball stuffers or in tlacoyos along with being used as dressings for meats. The season to consume them is between March and May. These insect possess mineral salts; some are very rich in calcium and have vitamins type B and are an important source of magnesium. In the larva state the provide a great quality of calories, now that they are made of fatty acids poli-unsaturated. $[7,8]$

\section{CONTEXTUAL LOCATION.}

Actopan, Hidalgo. It is located north of the city of Mexico, at a distance of $125 \mathrm{~km}$, and at only $37 \mathrm{~km}$ of the city of Pachuca de Soto, the capital of the state of Hidalgo. Actopan is widely known for its gastronomy, especially its barbacoa, as well as for the temple and exconvent of St. Nicólas de Tolentino. It has a population of 29,223 and holds the 8th place within the urban areas of the state of Hidalgo.

\section{Objective}

To analyze the use of the Thasus Gigas Burm insect, (Xamius), in the treatment aimed to control the Type 2 Diabetes Mellitus based on the opinion of adults within the Actopan Hidalgo population.

\section{METODOLOGY.}

A descriptive observational study of transverse characteristic is done through the aplication of surveys filled out by 50 adults within the Actopan population in the state of Hidalgo, Mexico for inclusion in the ongoing search for people with diabetes. In addition, exhaustively explored in order to obtain relevant information on the intake or entomofagia Thasus Gigas Burm (Xamuis).

Table 1. Taxonomic Data and habitat of the Thasus Gigas Burm (Xamuis o Chagüis). [6]

\begin{tabular}{|c|c|c|c|c|c|}
\hline Cientific Name & & Alternative Names & Order & Family & Diet and Proliferation \\
\hline Thasus Gigas Burm & & Xamoes Chagüis & Coleóptera & Coreidae & Mezquite Tress \\
\hline \multicolumn{6}{|c|}{ Table 2. Chemical analysis of the bedbug Thasus gigas (Xamuis) [7] } \\
\hline Sample & $\%$ Protein & $\%$ Fat & & $\%$ Crude fiber & $\%$ Ash \\
\hline II & $66.1 \mathrm{~b}$ & $23.1 \mathrm{a}$ & & $3.0 \mathrm{~b}$ & $2.0 \mathrm{a}$ \\
\hline II & $66.3 \mathrm{~b}$ & 21.3ab & & $4.5 \mathrm{a}$ & $2.1 \mathrm{a}$ \\
\hline IV & $66.7 \mathrm{~b}$ & $20.4 a b$ & & $4.8 \mathrm{a}$ & $2.2 \mathrm{a}$ \\
\hline $\mathrm{V}$ & $70.8 \mathrm{a}$ & $18.8 \mathrm{~b}$ & & $4.8 \mathrm{a}$ & $2.5 \mathrm{a}$ \\
\hline
\end{tabular}

Values with the same letter within a column are statistically equal Duncan $\alpha=0.05$

Figure 1. The times of proliferation can be found between summer and autum Thasus Gigas Burm (Chagüis). [9]
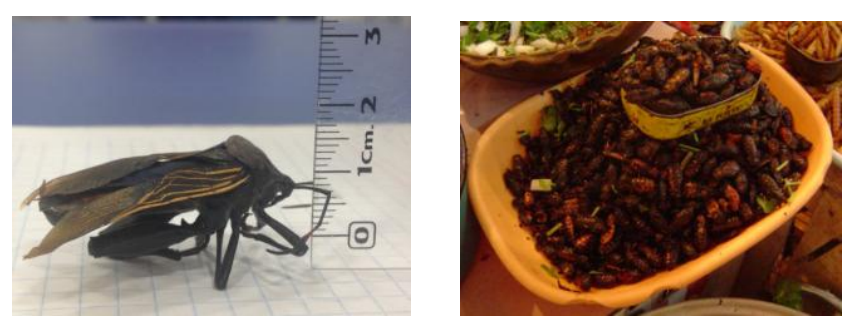


\section{RESULTS.}

As a result of the surveys conducted, it was detected that a $90 \%$ of the people asked knew of the insect, $10 \%$ (table 2) were not aware of it, the average age of the people was of which $22 \%$ presented with diabetes with a higher frequency in women (table 3). In general they state that the insects are important for the control of the levels of serum sugar, but it is an scientifically unexplored territory, it has only been studied from a culinary perspective. People point out eating them; they eat them in a state known as ninfal. A merchant of these insects mentioned the following, "They grow exclusively on the Prosopis spp (mezquite tree), and must be grabbed correctly otherwise they will taste sour instead of tasteful"', people eat them because they are good for diabetes.

Table 2. Knowledge and presence of diabetes in the sample studied

\begin{tabular}{llll}
\hline Variable & yes & no & \% \\
\hline you know & $45(90 \%)$ & $5(10 \%)$ & 100 \\
Diabetes & $11(22 \%)$ & $39(78 \%)$ & 100 \\
\hline
\end{tabular}

Source: Direct. Survey of adults in Actopan Hidalgo Mexico.

Table 3.Frecuency of gender, knowledge and diabetes in the sample studied.

\begin{tabular}{llll}
\hline Variable & Male & Female & \% \\
\hline Gender & 32 & 18 & 100 \\
you know & 29 & 16 & 90 \\
diabetes & 5 & 6 & 22 \\
\hline
\end{tabular}

Source: Direct. Survey of adults in Actopan Hidalgo Mexico.

\section{DISCUSSION}

It is of extreme importance to point out that there is an integration and development of microbusiness that are in charge of commercializing and exporting such food, while also mentioning that many times without taking into consideration that there is a great diversity of insects that can be hurtful and not beneficial. Because of a diversity of factors that have improved the capacity of communication and commercialization of such insect, it has been demonstrated that they can be of high importance and social impact, for its great nutritional properties, its ability to survive before any type of environmental collapse, including nuclear, and on the other hand the high number of diseases that are being presented in the juvenile and infancy population, researchers in the nutrition sector suggest the reincorporation of the consumption of some insects, whose previous studies have proved them be beneficial.

There have been 500 species of bugs, grasshoppers, ants, slugs, escamols, jumils, crickets, wasp that have passed with excellent scores the trials of their nutritional components, and the chemical substances that they hold allows them to be digested with ease.

For which it is important to conduct a thorough investigation about the "chagüis", whose study has yet to be done, in order to guide the population about the characteristics of the edible insects, the advantage of their consumption on the human's health and the way they can be prepared.

Through the empirical knowledge acquired by the people of the population, it is suggested that an investigation about the structural, biological and physiological characteristics of the "Chagüis" is conducted, and in fact from a toxicological aspect, which apparently has not been studied, and some people say that a high consumption induces hyperthermia, its therapeutic qualities have yet to be determined and this makes it a subject of alternative medicine especially with those who are economically vulnerable, but even more so it represents an emerging subject derived from some people claiming to have left their medical treatment which entails a risk within itself, and without a true foundation having to trust in the Entomophagy of these methods for metabolic control of their glucose, which is a situation yet to be experimented upon from a scientific point.

Despite all the advancements in medicine a cure for diabetes has not been yet discovered. The data collected through the interviews showed that home remedies are popular among communities such as those in Actopan. One of the reasons why alternative and natural medical remedies are commonly used is due to the lack of access to a health insurance services and to the lack of economical possibilities to afford allopathic medicine. Moreover, the main reason why these insects are highly consumed by the inhabitants of the communities is because they feel that their health is improved and the symptomatology of diabetes reduces. [9] Finally it was verified that if definitely the population claims to find improvement, consuming chahuis and its consumption is associated not only diabetes but also other diseases, whence opens the door to performing various research projects where the results of this research may be a antecedent in terms of therapeutic-pharmacological, because even are used in the preparation of sauces or other typical dishes of this region, do not lose sight that these could represent a delicious option for chronic disease control, such as type II diabetes mellitus. [10] 7\% of people with type II diabetes mellitus in his speech say have lost attachment in your medical treatment for diabetes control; this confers the emergency to realize glucose measurements in people of this population, who eat the chahuis bedbug with or without medical treatment for type II Diabetes Mellitus. Therefore this dish would be besides a cultural tradition an option for wellbeing population. [10] 


\section{CONCLUSIONS.}

The surveys conducted denote that people consume the insects as part of their diet, and with therapeutics objectives, therefore it is necessary to conduct biochemical studies to be able to elucidate the effect on the levels of glucose and define if in reality they represent an alternative for its control.

There is a possibility that the inadequate preparation when consumed as anutrition source as well as eating them raw is related to hyperthermia mentioned by a few people derived from the ingestion of some biological agent.

\section{ACKNOWLEDGEMENTS.}

The authors of the present research article would like to acknowledge and truly thank the collaboration of Yesenia Elizabeth Ruvalcaba Cobián who has a B.A in Teaching English as a Foreign Language, and Samantha Latorre Cervantes for her contributions on the revision and translation of the article; situation which allows the possibility to increase the transferring and modification of scientific knowledge.

The authors declare that no conflict of interests for the publication of this research paper.

\section{REFERENCES.}

[1]. Alberto Calderón Montero. Diabetes Mellitus: Epidemiology, Genetics and Pathogenetic Mechanisms. Revista Española de cardiología. 2007: 7 (8); 3-11

[2]. BOLETÍN EPIDEMIOLÓGICO DIABETES MELLITUS TIPO 2 PRIMER TRIMESTRE-2013, Dirección General de Epidemiología, Secretaria de Salud. Epidemiología Manual de Procedimientos Estandarizados para la Vigilancia Epidemiológica de la Diabetes Mellitus tipo 2

[3]. Secretaría de Salud Manual de Procedimientos Estandarizados para la Vigilancia Epidemiológica de la Diabetes Mellitus tipo 2 Subsecretaría de Prevención y Promoción de la Salud Dirección General de Epidemiología. Available online, 2013 in: http://webcache.googleusercontent.com/search?q=cache:BgtlP3iDgIkJ:www.epidemiologia.salud.gob.mx/doctos/infoepid/vig_ep id_manuales/10_2012_Manual_DM2_vFinal_31 oct12.pdf $+\& c d=1 \& \mathrm{hl}=\mathrm{en} \& \mathrm{ct}=\mathrm{clnk} \& \mathrm{gl}=m x$

[4]. Guías ALAD de diagnóstico, control y tratamiento de la Diabetes Mellitus Tipo 2, online 2013. available in: http://www.aladlatinoamerica.org/phocadownload/guias\%20alad.pdf

[5]. Journal of Ethnobiology and Ethnomedicine 2006, Julieta Ramos-Elorduy 2:51 doi:10.1186/1746-4269-2-51

[6]. axonomia de Thasus gigas. Online 2013. Available in: http://unibio.unam.mx/irekani/handle/123456789/5515?proyecto=Irekani

[7]. Mendoza, M.N. et al. Utilización del "xamui" (Thasus gigas) en la elaboración y conservación de una salsa tradicional del valle del mezquital.

[8]. Braylovsky, H. Mayorga, C. Ortega L, G. y Barrera, E. Estadios ninfales de los coreidos del Valle de Tehuacan, Puebla, México (Hemiptera-Heteroptera) II. Especies asociadas a huizacheras (Acacia spp.) y Mezquiteras (Prosopis spp): Mozena lunata, Pachylis hector, Savius jurgiosus y Thasus gigas. Annales Inst. Biol UNAM, Ser. Zool. 66 (1)1995: 57-80.

[9]. Echavarría Flores M, García Torres ME, Calderón Ordoñez MB, Olvera Luna AG, Ruvalcaba Ledezma JC. The bedbug "Xamuis" (Thasus gigas), a new treatment for diabetes or nutrimental culture. Int. J. Res. Ayurveda Pharm 2013; 4 suppl 6: 881884

[10]. Zamora López MC, Jiménez Pérez AJ, ' Castillo Sandoval A,García García MA, Canales Martínez ME, Ruvalcaba Ledezma JC.Intake of the "Chahuis" Bedbug Thasus Gigas Burn (Xamues) By Diabetic Patients for Glucose Control. IOSR J. of Pharm. 2014: 4(2); 44-45 